\title{
Experimental investigation on performance, smoke and exhaust gas analysis of four stroke diesel engine using pongomia/neem oil biodiesel
}

\author{
${ }^{1 *}$ Naresh Kumar Konada, ${ }^{2}$ K.N.S. Suman, ${ }^{3}$ B.B. Ashok Kumar \\ ${ }^{1 *}$ Department of Mechanical Engineering, Anits Engineering College, Visakhapatnam, INDIA \\ ${ }^{2}$ Department of Mechanical Engineering, AU College of Engineering, Andhra University, Visakhapatnam, INDIA \\ ${ }^{3}$ Department of Mechanical Engineering, Anits Engineering College, Visakhapatnam, INDIA \\ "Corresponding Author: e-mail: nareshkonada@ gmail.com, Tel +91-9949717058 \\ ORCID iDs: https://orcid.org/ 0000-002-9753-7829 (Konada), https://orcid.org/ 0000-003-1793-9690 (Suman), https://orcid.org/ 0000-002-9753-7829 (Kumar)
}

\begin{abstract}
Increase in energy demand, stringent emission norms and depletion of oil resources led to the discovery of alternative fuels for internal combustion engines. Many alternative fuels like alcohols, petroleum gas, and compressed natural gas have been already commercialized in the transport sector. In the present work, Pongomia oil and Neem oil are blended with diesel and used as an alternate fuel for CI engines. The Pongomia oil and Neem oil can be converted into bio diesel using a chemical process of transesterification.Different proportions of fuel blends have been produced by the process of blending bio diesel consisting of $10 \%$, $15 \%, 20 \%, 25 \%$, and 30\% (B10, B15, B20, B25, B30). The fuel properties of each blend are determined. The load test along with smoke and exhaust gas analysis of 4- Stroke Diesel engine using the blends of Pongomia oil and Neem oil with diesel are done in this study. The performance parameters of an engine are calculated for different blends. The sustainability of using alternate fuels in Diesel engines, especially the potential use of Pongomia oil and Neem oil as biodiesel have been brought to the fore through this work and suitable blends of bio diesel is suggested from the results.
\end{abstract}

Keywords: 4-Stroke Diesel Engine, Pongomia and Neem oil Bo diesel, Performance, Smoke and exhaust gas analysis.

DOI: http://dx.doi.org/10.4314/ijest.v12i4.3

Cite this article as:

Konada N.K., Suman K.N.S., Ashok Kumar B.B. 2020. Experimental investigation on performance, smoke and exhaust gas analysis of four stroke diesel engine using pongomia/neem oil bio diesel. International Journal of Engineering, Science and Technology, Vol. 12, No. 4, pp. 23-40. doi: 10.4314/ijest.v12i4.3

Received: June 2, 2020; Accepted: July 14, 2020; Final acceptance in revised form: July 23, 2020

\section{Introduction}

The demand for alternative or advanced fuels in the automotive industry is always required to replace existing petrol and diesel fuels. Bio diesel can act as a substitute replacement for gaseous fuels to decrease the emissions released from an automobile. Probably in this century, it is believed that crude oil and petroleum products will become very scarce and costly to find and produce. Although fuel economy of engines is greatly improved, increase in the number of automobiles alone dictates that there will be a great demand for fuel in the near future. Alternative fuel technology, availability, and use is must and will become more common in the coming decades. Another reason motivating the development of alternative fuels for the IC-engine is concerned over the emission problems of gasoline engines. Combined with air polluting systems, the large number of automobiles is a major contributor to the air quality problem of the world. A third reason for alternative fuel development is the fact that a large percentage of crude oil must be imported from other countries which control the larger oil fields. Many researchers have reported 
that vegetable oils can act as a substitute fuel and they are obtained from renewable sources. It was also noticed that, vegetable oils tend to produce less toxic emission as compared to conventional diesel

Biodiesel is a clean burning alternative fuel produced from domestic, renewable resources. The fuel is a mixture of fatty acid alkyl esters made from vegetable oils, animal fats or recycled greases. Where available, biodiesel can be used in compressionignition (diesel) engines in its pure form with little or no modifications. Few researchers have carried their work to replace conventional fuels with alternative bio fuels. Rajesh et al. (2019) conducted a study on optimization of biodiesel production from waste frying palm oil using definitive screening deisgn. It was observed from results that a maximum yield of $96.23 \%$ was achieved at a molar ratio of $6: 1$ and reaction temperature of $55^{\circ} \mathrm{C}$ and catalytic concentration of $1 \mathrm{wt} \%$ and the method of definitive screening give maximum yield. The same method of definitive screening was done for the present fuels of pongomia and neem oils and observed that incremental of $5 \mathrm{wt} \%$ gives maximum yield. Kapoor et al. (2020) investigated the performance and emissions of compression ignition engine with neem methyl ester mixed with cerium oxide nano particles. The results reveal that, nano particle mixed blends of neem methyl ester and die thy ester enhances the performance characteristics and reduce harmful emissions. Gurbuj et al. (2020) conducted a study on dual fuel combustion by different port injection fuels (neat ethanol and E85) in a DE95 diesel ethanol blend CI Engine. The results showed that, dual fuel combustion achieved low brake thermal efficiency and combustion efficiency compared to single diesel fuel combustion. In dual fuel combustion premixed E85 fuel offered higher engine efficiency and lower exhaust emission ratio than E100. Yan et al. (2020) conducted a study on experimental investigation on mixed combustion characteristics of coal, tobacco, straw, and cylinder in an energy saving bake process. It was observed from results that a composite fuel with $40 \%$ tobacco straw, $10 \%$ coal cyinder has two advantages. It can burn quickly and keep continuous combustion of the fixed carbon in coal at high temperature range. Senthilkumar et al. (2015) investigated on performance of palm methyl ester bio diesel in diesel engines. Experiments were conducted for blend percentages of 20\%, $40 \%$, $45 \%$, and $50 \%$. Author observed that, blend of $40 \%$ multi functional fuel additives exhibits minimal power drop and reduced emissions.

Nagaraj et al. (2019) conducted a study on Jatropa and Pongomia bio fuel in diesel engines with 3 and 4 hole nozzle diesel engines. Author conducted a study for 80:20 diesel and bio diesel ratio. It was observed that, the 3 hole nozzle engine exhibits optimum level of performance with low emissions. (Amit Kishore pandian et al 2018) performed a study on emission and performance analysis of a diesel engine burning cashew nut shell bio diesel with hexanol. It was observed from this study adding hexanol at $10 \%$ and $20 \%$ by volume to cashew nut shell bio fuel can results in decrease of emissions from the engine. Prakash et al. (2018) conducted a study on ternary blends of bio ethanol diesel and castor oil on the performance of the engine. It was observed from results that, ternary blend of neat castor oil-diesel-bio ethanol with volume ratios 40/30/30 is optimum. The thermal efficiency is observed to be $31.25 \%$ and has a smoke emission of $68 \%$. These results are observed to be closer to the diesel fuel.

Few more authors are also conducted their studies on different bio fuels and studied the performance of the engine. Based on all these experimental studies of various authors, selection of appropriate volume percentage of additives in the diesel or generation of new bio fuel alternative to diesel are always a challenging task. Hence, an attempt was made in this study to include Pongomia and neem oil as bio diesel for diesel engines. The significance of the work is to develop an alternative fuel using transeterification process to replace with current existing diesel fuel and reduce the emissions released from automobiles. The challenging task is to improve the performance characteristics of the engine compare pure diesel. Hence with in this work an attempt was made to reduce emissions released from the engine with different bio fuel blends of pongomia and neem oil in diesel and studied performance characteristics of the engine. Pongomia seeds are procured from Araku valley Visakhapatnam and crushed to obtain oil from the seeds. These pongomia and neem oils are mixed in proportions of various blends B10, B15, B20, B25, B30 and compared the performance with existing diesel fuel.

\section{Synthesis of bio diesel}

Biodiesel is produced through a process known as Trans-Esterification of triglycerides to methyl esters with methanol, a balanced and catalysed reaction. An excess of Methanol is required to obtain a high degree of conversion. Pongomia and neem oils are among the main vegetable oil candidates for biodiesel uses. Vegetable oils are becoming a promising source for the production of diesel fuel, because they are renewable in nature and environmental friendly as well. Edible vegetable oils (sun flower, canola, palm, soybean, and corn) and non-edible vegetable oils (Jatropha curcas, tallow and neem oil) are used for biodiesel production and found to be good as a diesel substitute. Pinnata is found almost all part of India mainly in the Western Ghats of India and it grows on any types of soil ranging from clayey to sandy. Pongamia pinnata is a native to many countries including India, Malaysia, Indonesia, Taiwan, Bangladesh, Sri Lanka and Myanmar. The Pongamia pinnata kernel contains about $30-40 \%$ of oil and hence, it is considered as a potential source for the biodiesel production. Neem tree is evergreen tree growing in almost every state of India. It is native to Indian subcontinent, Southeast Asian countries and it grows all over India. It grows in all kinds of soil and in drier areas.

\subsection{Methodology of Trans-Esterification Process of Pongomia and Neem Oils}

Pongomia oil was collected from a local arena in Visakhapatnam district (Araku tourist place). Potassium hydroxide flakes, methanol (AR Grade), and diethyl ether were procured from the Chemical laboratory, Anits. The mixture was stirred at the same 
speed for all test runs as shown in Fig 1. All experiments of trans esterification reaction were performed in a $250 \mathrm{~mL}$ round-bottom flask equipped with a water-cooled reflux condenser. A hot plate with magnetic stirrer arrangement was used for heating the mixture in the flask. The microwave-assisted transesterification was performed using a modified domestic microwave oven with an output power of $800 \mathrm{~W}$. The microwave oven was modified and fitted with a temperature reader, an external agitator and a water- cooled reflux condenser. The transesterification process was widely used in bio-diesel production from different biomass materials. The process consists of two steps namely, acid esterification and alkali trans esterification.

Step 1) Acid esterification: Acid esterification reduces the FFA value of un- refined oil using an acid catalyst.

Step 2) Alkali trans- esterification: After removing the impurities of the pro- duct from the Step 1, it is trans-esterified to monoesters of fatty acids using an alkali catalyst.

The mechanism of synthesis of biodiesel via two-step transesterification process is represented as

Step 1)

$$
\mathrm{RCOOH}+\mathrm{CH}_{3} \mathrm{OH} \stackrel{\mathrm{H}_{2} \mathrm{SO}_{4}}{\rightarrow} \mathrm{RCOOH}_{3}+\mathrm{H}_{2} \mathrm{O}
$$

Step 2)
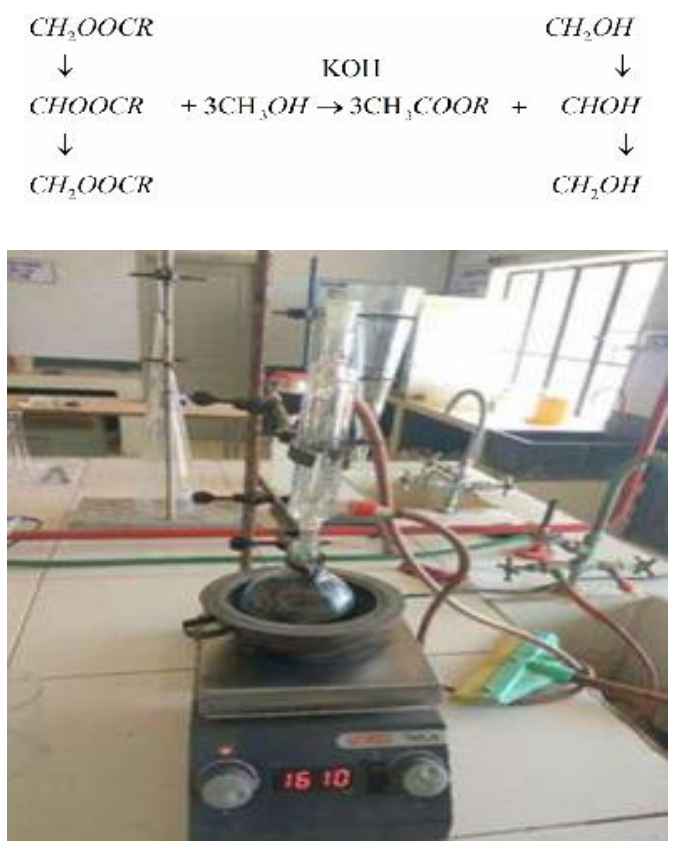

Figure 1. Trans-Esterification Process

\subsubsection{Draining of Glycerol}

After the transesterification reaction, we must wait for the glycerol to settle to the bottom of the container when kept in a separating funnel. This happens because Glycerol is heavier than biodiesel. The settling will begin immediately, but the mixture should be left for a minimum of eight hours to make sure all the glycerol has been settled out. The glycerol volume should be approximately $20 \%$ of the original oil volume. The objective is to remove only the glycerol and stop when the biodiesel is reached. Glycerol looks very dark compared to the yellow biodiesel as shown in Fig 2. The viscosity difference is large enough between the two liquids that the difference in flow from the drain can be seen. 


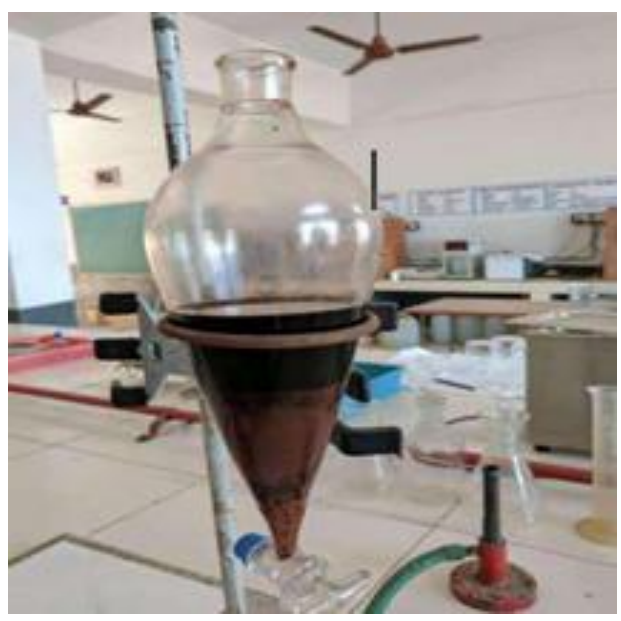

Figure 2. Separation of Glycerol and Esters

The methyl esters thus obtained from the trans-esterification of Pongomia oil are mixed with Neem oil which is referred as Biodiesel in this work. This Biodiesel is mixed with petroleum Diesel by the process of Blending with varying proportions to obtain various fuel blends.

\subsection{Blending of Oils}

In the general terminology to indicate the composition of Biodiesel as B5, B10, and B15 etc., where "B" represents the fuel as Biodiesel and the digit represents the percentage of blend. 10\% biodiesel, 90\% petro diesel is labeled as B10. $20 \%$ biodiesel, $80 \%$ petro diesel is labeled as B20. In this work, the fuel blends with their respective proportions of its constituents were used with a total quantity of $1000 \mathrm{ml}$ shown in Table 1.The blending of oils are done through a magnetic stirrer shown in Fig 3.

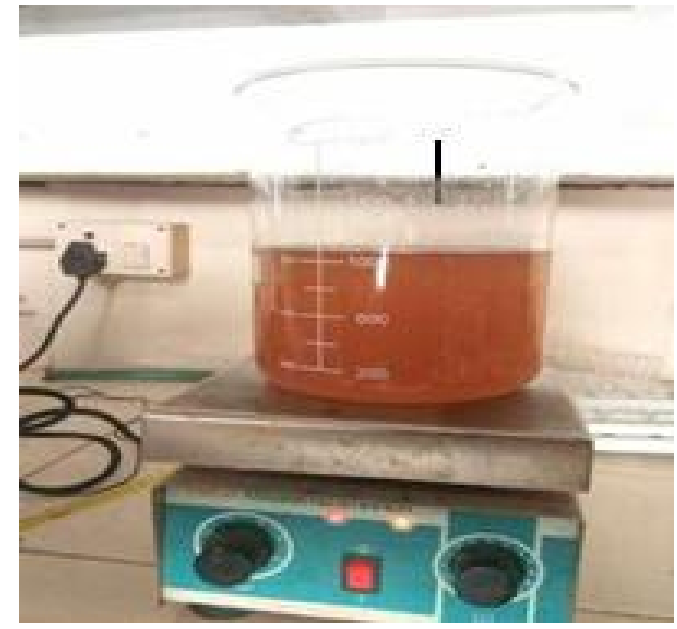

Figure 3. Blending of Oils using Magnetic Stirrer

Table 1. Oil Proportion in Fuel Blends

\begin{tabular}{|c|c|c|c|}
\hline Label & Diesel(ml) & $\begin{array}{c}\text { Pongomia } \\
\text { oil }(\mathrm{ml})\end{array}$ & $\begin{array}{c}\text { Neem } \\
\text { oil }(\mathrm{ml})\end{array}$ \\
\hline B10 & 900 & 50 & 50 \\
\hline B15 & 850 & 100 & 50 \\
\hline B20 & 800 & 150 & 50 \\
\hline B25 & 750 & 200 & 50 \\
\hline B30 & 700 & 250 & 50 \\
\hline
\end{tabular}




\subsubsection{Viscosity measurement}

A viscometer is an instrument used to measure the viscosity of a fluid. For liquids with viscosities which vary with flow conditions, an instrument called a rheometer is used. Viscometers only measure under one flow condition. The Fig 4 shows a viscometer for measuring viscosity of liquids. Redwood viscometer determines the viscosity in terms of seconds during uniform heating of oil passes through a standard orifice and collected in flask of 50 cc capacity. Redwood Viscometer No. 1 is used for fluids having viscosity corresponds to Redwood seconds less than 2000. Redwood Viscometer No. 2 is used for fluids having viscosity corresponds to Redwood seconds greater than 2000. The various properties of fuel blends flash point, fire point, calorific value, viscosity and specific gravity of B10, B15, B20, B25 and B30 blends are given in Table 2.

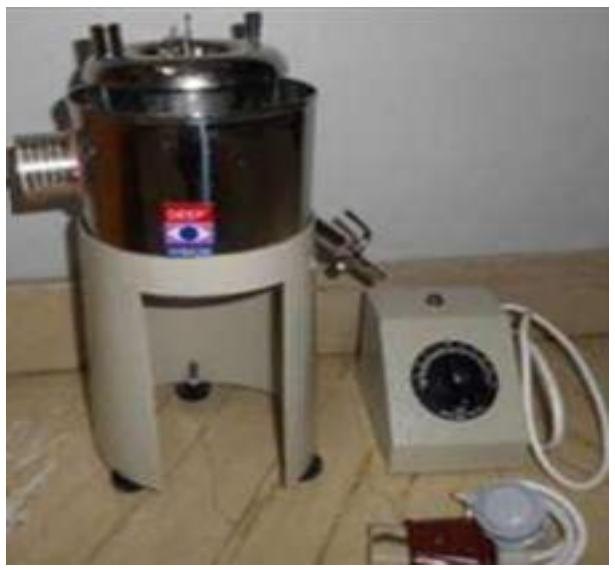

Figure 4. Viscometer Apparatus

Table 2 Properties of Oil Blends

\begin{tabular}{|l|r|r|r|r|r|}
\hline \multicolumn{1}{|c|}{ Properties } & \multicolumn{1}{c|}{ B10 } & \multicolumn{1}{c|}{ B15 } & \multicolumn{1}{c|}{ B20 } & \multicolumn{1}{c|}{ B25 } & \multicolumn{1}{c|}{ B30 } \\
\hline Flash Point $\left({ }^{\circ} \mathrm{C}\right)$ & 55 & 57 & 58 & 60 & 61 \\
\hline Fire Point $\left({ }^{\circ} \mathrm{C}\right)$ & 60 & 61 & 62 & 62 & 64 \\
\hline Viscosity $($ Centi poise $)$ & 0.00185 & 0.00365 & 0.01062 & 0.01676 & 0.02078 \\
\hline Specific gravity $(\mathrm{gm} / \mathrm{cc})$ & 0.82 & 0.83 & 0.83 & 0.84 & 0.84 \\
\hline Calorific value $(\mathrm{kJ} / \mathrm{kg})$ & 44948.6 & 44490.4 & 44032.7 & 43574.4 & 43116.4 \\
\hline
\end{tabular}

\section{Performance evaluation of diesel engine for various blends of oils}

The prepared fuel blends are tested in a Kirloskar make four stroke, single cylinder, constant speed, water-cooled diesel engine with maximum brake power 5HP and engine speed $1500 \mathrm{rpm}$, bore $80 \mathrm{~mm}$, stroke 110mm, and compression ratio 17.5:1. Provision is made to measure the exhaust heat with the help of a exhaust gas calorimeter and thermocouples fixed at salient points. This engine is provided with a crank handle for starting. The engine is mounted with an absorption dynamometer of brake drum type. The engine set up is also provided with burette, graduations duly marked and a three way valve is used to measure the fuel flow rate. A load test and a smoke analysis test are conducted with additional attachment of muffler to the exhaust smoke pipe. The procedure to conduct the test is given below in the following steps and the test rig to evaluate the performance of different blended oils are shown in Fig 5.

1. Check the fuel and lubricating oil systems before starting the engine.

2. Connect water supply to the engine and brake drum and remove all load on the brake drum.

3. Keep 3 way cock in horizontal position so that fuel flows from the tank to the engine filling the burette.

4. Start the engine by hand cranking and allow the engine to pick up rated speed.

5. Allow the engine to run for some time in idle condition.

6. Put the 3 way cock in vertical position and measure the fuel consumption rate by noting the time taken for 10 cc of fuel flow.

7. Experiment is repeated at different loads.

8. Engine is stopped after detaching load from the engine 


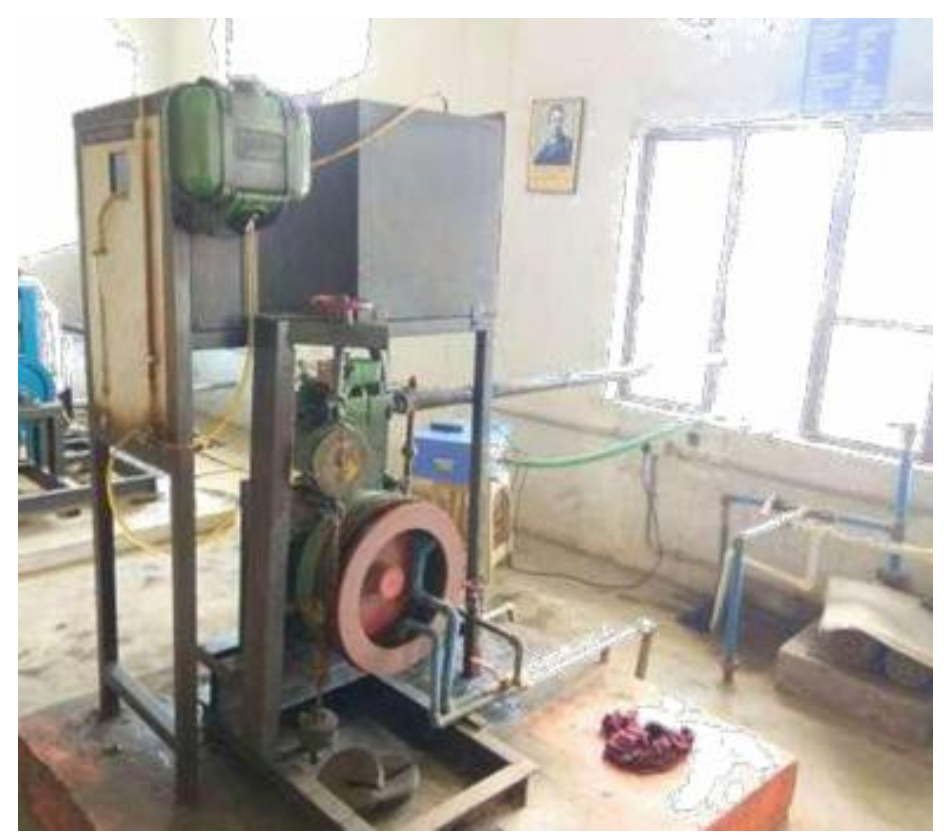

Figure 5. 4 -Stroke single cylinder vertical diesel engine

\subsection{Basic data calculation for engine}

Rated brake power of engine B.P $=5$ H.P $=3.7 \mathrm{~kW}$

Effective radius of the brake drum $\mathrm{R}=0.213 \mathrm{~m}$

Diameter of cylinder bore $\mathrm{D}=80 \times 10^{-3} \mathrm{~m}$
Speed of engine $\mathrm{N}=1500 \mathrm{rpm}$

Stroke length $\mathrm{L}=110 \times 10^{-3} \mathrm{~m}$

Time taken for 10cc consumption of fuel is ' $\mathrm{t}$ ' $\mathrm{sec}$

Maximum load $=\frac{\text { Rated BP } \times 60000}{2 \pi R N \times 9.81}=\frac{3.7 \times 60000}{2 \pi \times 0.213 \times 1500 \times 9.81}=11.27 \mathrm{Kg}$

Brake Power $(\mathrm{BP})=\frac{2 \pi N(W-S) \times 9.81 \times R}{60000}$

Fuel consumption $(\mathrm{FC})=\frac{10 \times \text { specific gravity } \times 3600}{t \times 1000} \frac{\mathrm{Kg}}{\mathrm{hr}}$

\section{Indicated power $(\mathrm{IP})=\mathrm{BP}+\mathrm{FP}$}

where FP is the frictional power obtained from the graph drawn between Brake Power and Fuel Consumption. The linear portion of the graph is extended to cut the negative of the $\mathrm{x}$-axis on which BP is taken. The length of intercept point from zero gives Frictional Power. This method of determining F.P. is known as Willian's Line Method.

Specific Fuel consumption $(\mathrm{SFC})=\frac{\mathrm{FC}}{B P} \frac{\mathrm{Kg}}{K w h r}$

Brake thermal efficiency $\eta_{b t h}=\frac{B P \times 3600}{F C \times C V}$

Indicated thermal efficiency $\eta_{i t h}=\frac{I P \times 3600}{F C \times C V}$

Mechanical efficiency $\eta_{\text {mech }}=\frac{B P}{I P}$ 
Indicated mean effective pressure $(\mathrm{IMEP})=\frac{\mathrm{IP} \times 60000}{L \times \frac{\pi}{4} D^{2} \times \frac{N}{2}} \frac{\mathrm{N}}{m^{2}}$

Brake mean effective pressure $(\mathrm{BMEP})=\frac{\mathrm{BP} \times 60000}{L \times \frac{\pi}{4} D^{2} \times \frac{N}{2}} \frac{\mathrm{N}}{m^{2}}$

\subsubsection{Calculation of performance parameters}

Considering B10 blend at $1.9 \mathrm{Kgf}$ load

Specific gravity is $0.82 \mathrm{gm} / \mathrm{cc}$

Calorific value is $44948.6 .6 \mathrm{~kJ} / \mathrm{kg}$

Brake Power(BP $)=\frac{2 \pi N(W-S) \times 9.81 \times R}{60000}=\frac{2 \pi \times 1500 \times 1.9 \times 9.81 \times 0.213}{60000}=0.6236 \mathrm{KW}$

Fuel consumption $(\mathrm{FC})=\frac{10 \times \text { specific gravity } \times 3600}{t \times 1000} \frac{\mathrm{Kg}}{\mathrm{hr}}=\frac{10 \times 0.82 \times 3600}{64 \times 1000}=0.476 \frac{\mathrm{Kg}}{\mathrm{hr}}$

Frictional power from graph $(\mathrm{FP})=2 \mathrm{~kW}$

Indicated power $(\mathrm{IP})=\mathrm{BP}+\mathrm{FP}=0.6236+2=2.6236 \mathrm{~kW}$

Specific Fuel consumption $(\mathrm{SFC})=\frac{\mathrm{FC}}{B P} \frac{\mathrm{Kg}}{K w h r}=\frac{0.476}{0.6236}=0.7633 \frac{\mathrm{Kg}}{\mathrm{Kwhr}}$

Brake thermal efficiency $\eta_{b t h}=\frac{B P \times 3600}{F C \times C V}=\frac{0.6236 \times 3600}{0.476 \times 44948.2}=10.49 \%$

Indicated thermal efficiency $\eta_{i t h}=\frac{I P \times 3600}{F C \times C V}=\frac{2.6236 \times 3600}{0.476 \times 44948.2}=44.14 \%$

Mechanical efficiency $\eta_{\text {mech }}=\frac{B P}{I P}=\frac{0.6236}{2.6236}=23.76 \%$

Indicated mean effective pressure $(\mathrm{IMEP})=\frac{\mathrm{IP} \times 60000}{L \times \frac{\pi}{4} D^{2} \times \frac{N}{2}} \frac{\mathrm{N}}{m^{2}}$

$$
=\frac{2.6236 \times 60000}{110 \times 10^{-3} \times \frac{\pi}{4}\left(80 \times 10^{-3}\right)^{2} \times \frac{1500}{2}}=379599 \frac{\mathrm{N}}{\mathrm{m}^{2}} \text { or } 3.795 \mathrm{bar}
$$

Brake mean effective pressure $(\mathrm{BMEP})=\frac{\mathrm{BP} \times 60000}{L \times \frac{\pi}{4} D^{2} \times \frac{N}{2}} \frac{\mathrm{N}}{m^{2}}$

$$
=\frac{0.6236 \times 60000}{110 \times 10^{-3} \times \frac{\pi}{4}\left(80 \times 10^{-3}\right)^{2} \times \frac{1500}{2}}=90226 \frac{\mathrm{N}}{\mathrm{m}^{2}} \text { or } 0.9 \mathrm{bar}
$$


The observations made from the experimental procedure during the Load test and Smoke analysis are tabulated in the following tables Table 3 to Table 8 .

Table 3 Performance parameters for Pure Diesel

\begin{tabular}{|c|c|c|c|c|c|c|c|c|c|c|c|}
\hline $\begin{array}{c}\text { Load( } \\
\mathrm{kgf})\end{array}$ & $\begin{array}{c}\text { Time 't' } \\
(\mathrm{sec})\end{array}$ & $\begin{array}{c}\mathrm{FC} \\
(\mathrm{kg} / \mathrm{hr})\end{array}$ & $\begin{array}{c}\mathrm{BP} \\
(\mathrm{kW})\end{array}$ & $\begin{array}{c}\mathrm{IP} \\
(\mathrm{kW})\end{array}$ & $\begin{array}{c}\text { SFC } \\
(\mathrm{kg} / \mathrm{kWhr})\end{array}$ & $\begin{array}{c}\eta_{\text {bth }} \\
(\%)\end{array}$ & $\begin{array}{c}\eta_{\text {ith }(\%)} \\
(\%)\end{array}$ & $\begin{array}{c}\text { IMEP } \\
\left(\mathrm{kN} / \mathrm{m}^{2}\right)\end{array}$ & $\begin{array}{c}\text { BMEP } \\
\left(\mathrm{kN} / \mathrm{m}^{2}\right)\end{array}$ & HSU \\
\hline 0 & 76 & 0.3789 & 0 & 2 & 0 & 0 & 41.6 & 0 & 289.25 & 0 & 0.43 \\
\hline 1.9 & 64 & 0.45 & 0.62 & 2.62 & 0.72 & 11 & 45.9 & 23.8 & 379.48 & 90.22 & 0.86 \\
\hline 3.8 & 56 & 0.5143 & 1.24 & 3.24 & 0.41 & 19 & 49.8 & 38.4 & 469.71 & 180.45 & 1.28 \\
\hline 5.6 & 48 & 0.6 & 1.83 & 3.83 & 0.32 & 24 & 50.4 & 47.9 & 555.19 & 265.9 & 2.97 \\
\hline 7.4 & 42 & 0.6857 & 2.42 & 4.42 & 0.28 & 28 & 50.9 & 54.9 & 640.67 & 351.42 & 6.65 \\
\hline 9.2 & 38 & 0.7579 & 3.02 & 5.02 & 0.25 & 31 & 52.2 & 60.2 & 726.15 & 436.90 & 9.81 \\
\hline
\end{tabular}

Table 4 Performance parameters for B10 blend

\begin{tabular}{|c|c|c|c|c|c|c|c|c|c|c|c|}
\hline Load(kgf) & $\begin{array}{l}\text { Time } \\
\text { 't' } \\
(\mathrm{sec})\end{array}$ & $\begin{array}{c}\mathrm{FC} \\
(\mathrm{kg} / \mathrm{hr})\end{array}$ & $\mathrm{BP}(\mathrm{kW})$ & $\begin{array}{c}\text { IP } \\
(\mathrm{kW})\end{array}$ & $\begin{array}{c}\text { SFC } \\
(\mathrm{kg} / \mathrm{kWhr})\end{array}$ & $\begin{array}{l}\eta_{\mathrm{bth}} \\
(\%)\end{array}$ & $\begin{array}{l}\eta_{\text {ith }} \\
(\%)\end{array}$ & $\eta_{\text {mech }}$ & $\begin{array}{l}\text { IMEP } \\
\left(\mathrm{kN} / \mathrm{m}^{2}\right)\end{array}$ & $\begin{array}{l}\text { BMEP } \\
\left(\mathrm{kN} / \mathrm{m}^{2}\right)\end{array}$ & HSU \\
\hline 0 & 90 & 0.33 & 0 & 1.85 & 0 & 0 & 44.8 & 0 & 267.56 & 0 & 0.43 \\
\hline 1.9 & 72 & 0.41 & 0.62 & 2.47 & 0.66 & 12.1 & 47.9 & 25.2 & 357.79 & 90.22 & 0.87 \\
\hline 3.8 & 68 & 0.43 & 1.24 & 3.09 & 0.35 & 22.8 & 56.7 & 40.2 & 448.02 & 180.45 & 1.71 \\
\hline 5.6 & 62 & 0.47 & 1.83 & 3.68 & 0.26 & 30.7 & 61.6 & 49.8 & 533.5 & 265.94 & 2.55 \\
\hline 7.4 & 58 & 0.51 & 2.42 & 4.27 & 0.21 & 37.9 & 66.8 & 56.7 & 618.98 & 351.42 & 2.97 \\
\hline 9.2 & 54 & 0.55 & 3.02 & 4.87 & 0.18 & 43.9 & 70.8 & 62 & 704.46 & 436.9 & 12.1 \\
\hline
\end{tabular}

Table 5 Performance parameters for B15 blend

\begin{tabular}{|c|c|c|c|c|c|c|c|c|c|c|c|}
\hline Load(Kgf) & $\begin{array}{c}\text { Time } \\
\text { 't' } \\
(\mathrm{sec})\end{array}$ & $\begin{array}{c}\mathrm{FC} \\
(\mathrm{Kg} / \mathrm{hr})\end{array}$ & $\mathrm{BP}(\mathrm{KW})$ & $\begin{array}{c}\mathrm{IP} \\
(\mathrm{KW})\end{array}$ & $\begin{array}{c}\mathrm{SFC} \\
(\mathrm{Kg} / \mathrm{KWhr})\end{array}$ & $\begin{array}{c}\eta_{\text {bth }} \\
(\%)\end{array}$ & $\begin{array}{c}\eta_{\text {ith }} \\
(\%)\end{array}$ & $\begin{array}{c}\eta_{\text {mech }} \\
(\%)\end{array}$ & $\begin{array}{c}\text { IMEP } \\
\left(\mathrm{KN} / \mathrm{m}^{2}\right)\end{array}$ & $\begin{array}{c}\text { BMEP } \\
\left(\mathrm{KN} / \mathrm{m}^{2}\right)\end{array}$ & HSU \\
\hline 0 & 83 & 0.36 & 0 & 0.85 & 0 & 0 & 19 & 0 & 122.93 & 0 & 0.43 \\
\hline 1.9 & 69 & 0.43 & 0.62 & 1.47 & 0.69 & 11.6 & 27.4 & 42.3 & 213.16 & 90.22 & 1.28 \\
\hline 3.8 & 67 & 0.44 & 1.24 & 2.09 & 0.35 & 22.6 & 37.9 & 59.4 & 303.39 & 180.45 & 1.71 \\
\hline 5.6 & 55 & 0.54 & 1.83 & 2.68 & 0.29 & 27.3 & 39.9 & 68.3 & 388.87 & 265.94 & 2.13 \\
\hline 7.4 & 44 & 0.68 & 2.42 & 3.27 & 0.28 & 28.9 & 39 & 74 & 474.35 & 351.42 & 6.65 \\
\hline 9.2 & 37 & 0.8 & 3.02 & 3.87 & 0.26 & 30.2 & 38.7 & 78 & 559.83 & 436.9 & 10.96 \\
\hline
\end{tabular}

Table 6 Performance parameters for B20 blend

\begin{tabular}{|c|c|c|c|c|c|c|c|c|c|c|c|}
\hline Load(Kgf) & $\begin{array}{c}\text { Time } \\
\text { 't' } \\
(\mathrm{sec})\end{array}$ & $\begin{array}{c}\mathrm{FC} \\
(\mathrm{Kg} / \mathrm{hr})\end{array}$ & $\mathrm{BP}(\mathrm{KW})$ & $\begin{array}{c}\mathrm{IP} \\
(\mathrm{KW})\end{array}$ & $\begin{array}{c}\text { SFC } \\
(\mathrm{Kg} / \mathrm{KWhr})\end{array}$ & $\begin{array}{l}\eta_{\text {bth }} \\
(\%)\end{array}$ & $\begin{array}{l}\eta_{\text {ith }} \\
(\%)\end{array}$ & $\begin{array}{c}\eta_{\text {mech }} \\
(\%)\end{array}$ & $\begin{array}{c}\text { IMEP } \\
\left(\mathrm{KN} / \mathrm{m}^{2}\right)\end{array}$ & $\begin{array}{c}\text { BMEP } \\
\left(\mathrm{KN} / \mathrm{m}^{2}\right)\end{array}$ & HSU \\
\hline 0 & 86 & 0.35 & 0 & 2.1 & 0 & 0 & 49 & 0 & 303.71 & 0 & 0.43 \\
\hline 1.9 & 69 & 0.43 & 0.62 & 2.72 & 0.69 & 11.6 & 51 & 22.9 & 393.94 & 90.22 & 0.86 \\
\hline 3.8 & 59 & 0.51 & 1.24 & 3.34 & 0.4 & 19.9 & 53.6 & 37.2 & 484.17 & 180.45 & 1.71 \\
\hline 5.6 & 51 & 0.59 & 1.83 & 3.93 & 0.32 & 25.4 & 54.5 & 46.6 & 569.65 & 265.94 & 2.97 \\
\hline 7.4 & 49 & 0.61 & 2.42 & 4.52 & 0.25 & 32.3 & 60.2 & 53.6 & 655.14 & 351.42 & 3.38 \\
\hline 9.2 & 37 & 0.81 & 3.02 & 5.12 & 0.26 & 30.3 & 51.4 & 58.9 & 740.62 & 436.9 & 9.03 \\
\hline
\end{tabular}


Table 7 Performance parameters for B25 blend

\begin{tabular}{|c|c|c|c|c|c|c|c|c|c|c|c|}
\hline Load(Kgf) & $\begin{array}{c}\text { Time } \\
\text { 't' } \\
(\mathrm{sec})\end{array}$ & $\begin{array}{c}\mathrm{FC} \\
(\mathrm{Kg} / \mathrm{hr})\end{array}$ & $\mathrm{BP}(\mathrm{KW})$ & $\begin{array}{c}\mathrm{IP} \\
(\mathrm{KW})\end{array}$ & $\begin{array}{c}\mathrm{SFC} \\
(\mathrm{Kg} / \mathrm{KWhr})\end{array}$ & $\begin{array}{c}\eta_{\mathrm{bth}} \\
(\%)\end{array}$ & $\begin{array}{c}\eta_{\text {ith }} \\
(\%)\end{array}$ & $\begin{array}{c}\eta_{\text {mech }} \\
(\%)\end{array}$ & $\begin{array}{c}\text { IMEP } \\
\left(\mathrm{KN} / \mathrm{m}^{2}\right)\end{array}$ & $\begin{array}{c}\text { BMEP } \\
\left(\mathrm{KN} / \mathrm{m}^{2}\right)\end{array}$ & HSU \\
\hline 0 & 70 & 0.43 & 0 & 1.8 & 0 & 0 & 34.3 & 0 & 260.33 & 0 & 0.43 \\
\hline 1.9 & 62 & 0.48 & 0.62 & 2.42 & 0.78 & 10.5 & 40.9 & 25.7 & 350.56 & 90.22 & 1.71 \\
\hline 3.8 & 55 & 0.55 & 1.24 & 3.04 & 0.44 & 18.7 & 45.6 & 40.9 & 440.79 & 180.45 & 2.55 \\
\hline 5.6 & 50 & 0.6 & 1.83 & 3.63 & 0.32 & 25 & 49.5 & 50.5 & 526.27 & 265.94 & 3.38 \\
\hline 7.4 & 43 & 0.7 & 2.42 & 4.22 & 0.29 & 28.4 & 49.5 & 57.4 & 611.75 & 351.42 & 8.63 \\
\hline 9.2 & 38 & 0.79 & 3.02 & 4.82 & 0.26 & 31.2 & 49.9 & 62.6 & 697.23 & 436.9 & 22.74 \\
\hline
\end{tabular}

Table 8 Performance parameters for B30 blend

\begin{tabular}{|c|c|c|c|c|c|c|c|c|c|c|c|}
\hline Load(Kgf) & $\begin{array}{c}\text { Time } \\
\text { 't' } \\
(\mathrm{sec})\end{array}$ & $\begin{array}{c}\text { FC } \\
(\mathrm{Kg} / \mathrm{hr})\end{array}$ & $\mathrm{BP}(\mathrm{KW})$ & $\begin{array}{c}\mathrm{IP} \\
(\mathrm{KW})\end{array}$ & $\begin{array}{c}\text { SFC } \\
(\mathrm{Kg} / \mathrm{KWhr})\end{array}$ & $\begin{array}{c}\eta_{\text {bth }} \\
(\%)\end{array}$ & $\begin{array}{c}\eta_{\text {ith }} \\
(\%)\end{array}$ & $\begin{array}{c}\eta_{\text {mech }} \\
(\%)\end{array}$ & $\begin{array}{c}\text { IMEP } \\
\left(\mathrm{KN} / \mathrm{m}^{2}\right)\end{array}$ & $\begin{array}{c}\text { BMEP } \\
\left(\mathrm{KN} / \mathrm{m}^{2}\right)\end{array}$ & HSU \\
\hline 0 & 87 & 0.35 & 0 & 1.15 & 0 & 0 & 27.3 & 0 & 166.32 & 0 & 0.43 \\
\hline 1.9 & 69 & 0.44 & 0.62 & 1.77 & 0.7 & 11.7 & 33.4 & 35.1 & 256.55 & 90.22 & 2.55 \\
\hline 3.8 & 61 & 0.5 & 1.24 & 2.39 & 0.4 & 20.8 & 40 & 52 & 346.78 & 180.45 & 3.38 \\
\hline 5.6 & 50 & 0.61 & 1.83 & 2.98 & 0.33 & 25.1 & 40.8 & 61.5 & 432.26 & 265.94 & 4.62 \\
\hline 7.4 & 43 & 0.7 & 2.42 & 3.57 & 0.29 & 28.5 & 42.1 & 67.8 & 517.74 & 351.42 & 9.81 \\
\hline 9.2 & 37 & 0.82 & 3.02 & 4.17 & 0.27 & 30.5 & 42.2 & 72.4 & 603.22 & 436.9 & 22.41 \\
\hline
\end{tabular}

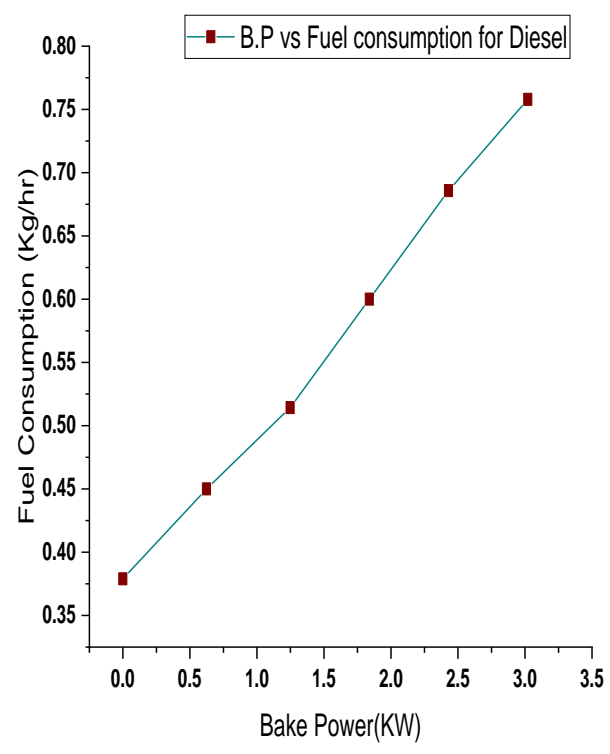

Figure 6. BP vs Fuel Consumption for diesel

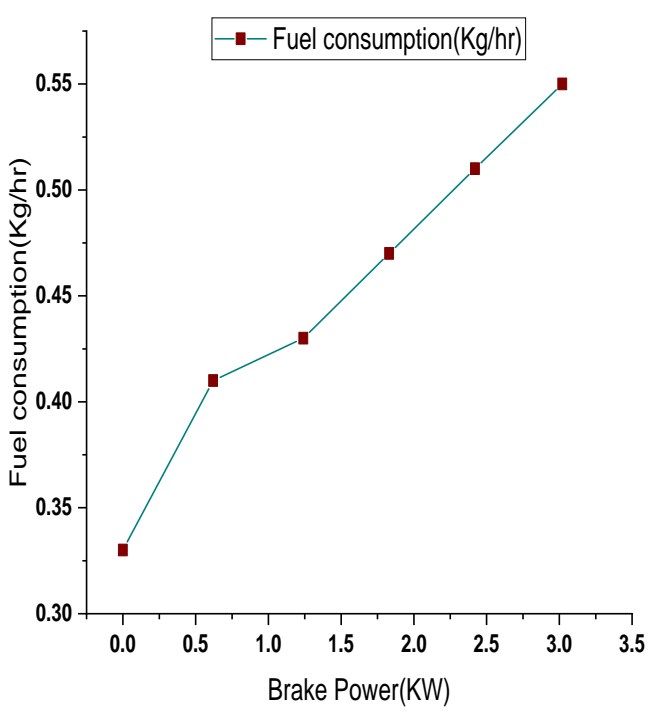

Figure 7. BP vs Fuel Consumption for B10 blend 


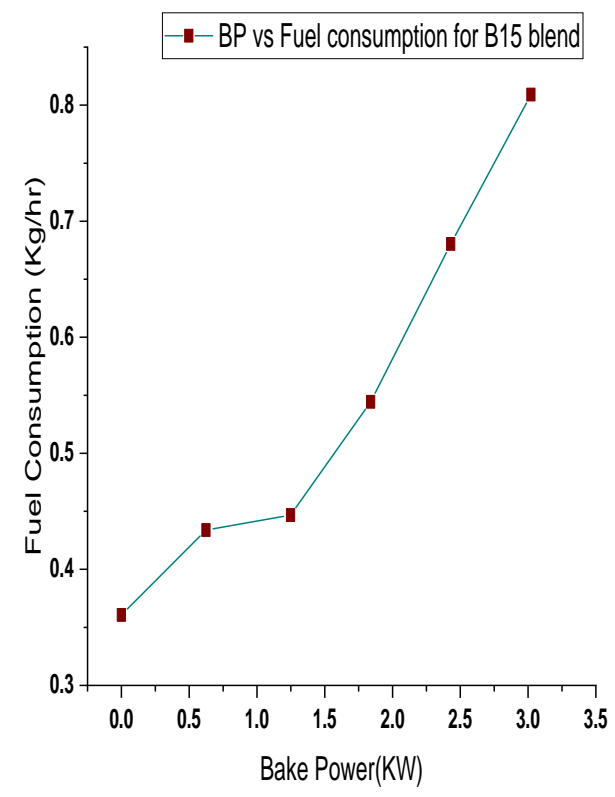

Figure 8. BP vs Fuel Consumption for B15 blend

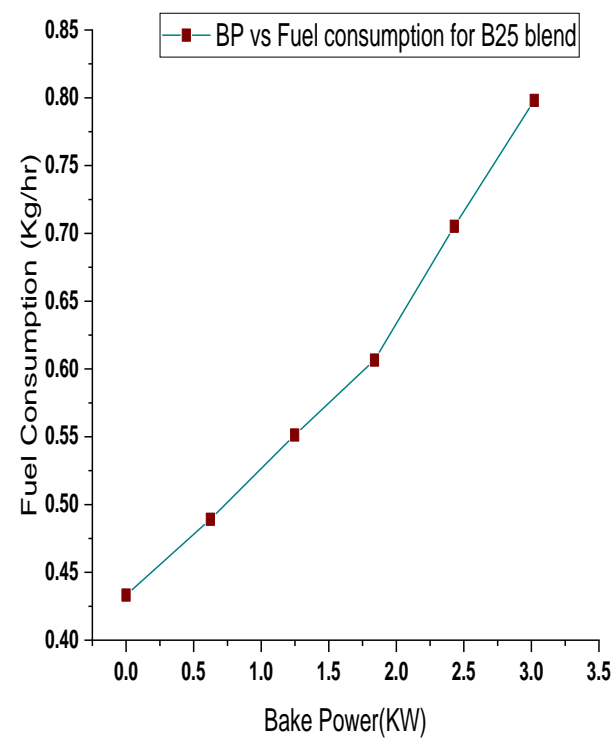

Figure10. BP vs Fuel Consumption for B25 blend

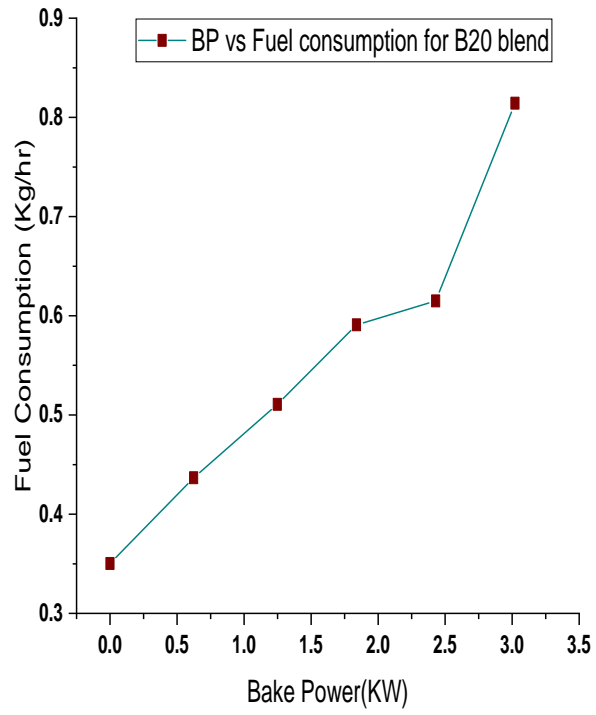

Figure 9. BP vs Fuel Consumption for B20 blend

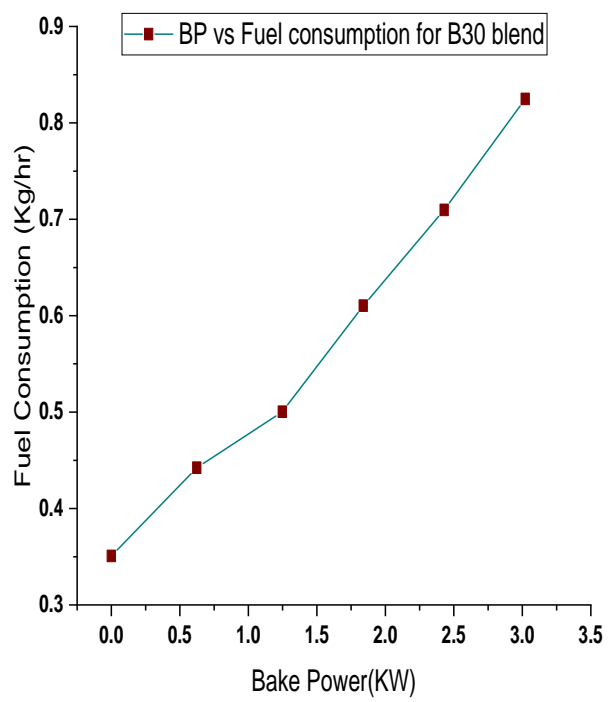

Figure 11. BP vs FC for $\mathrm{B} 30$ blend 


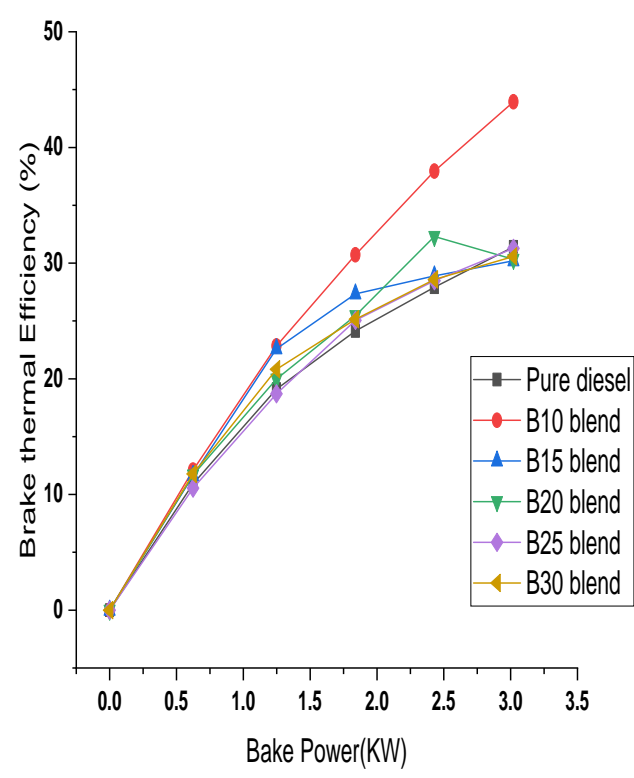

Figure 12. BP vs Brake thermal efficiency

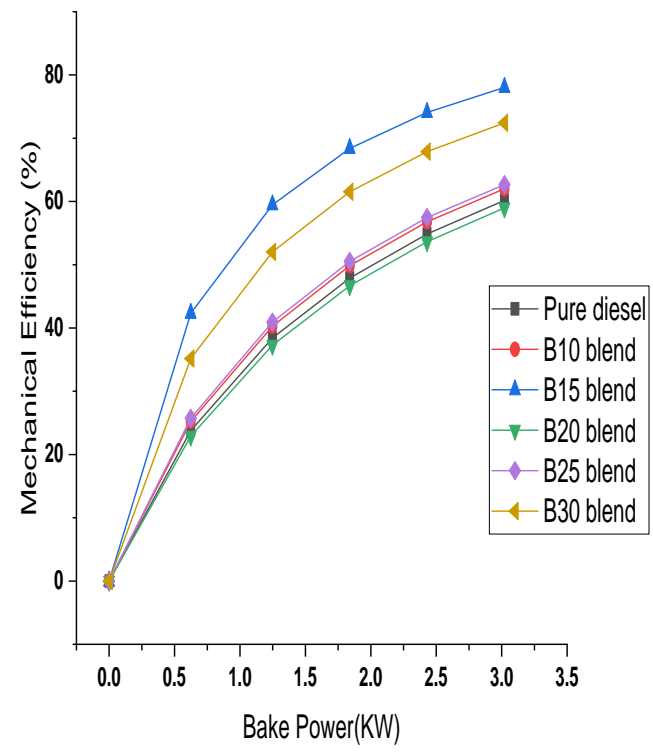

Figure 14. BP vs Mechanical efficiency

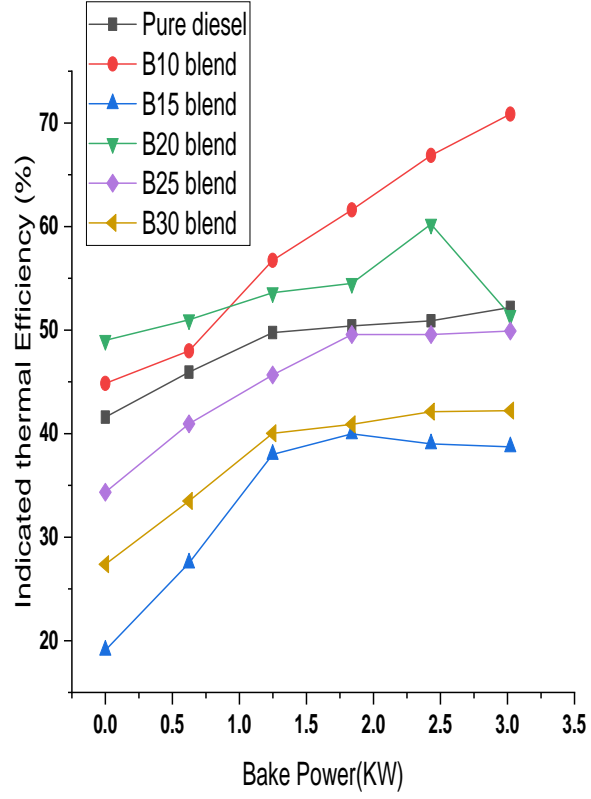

Figure 13. BP vs Indicated thermal efficiency

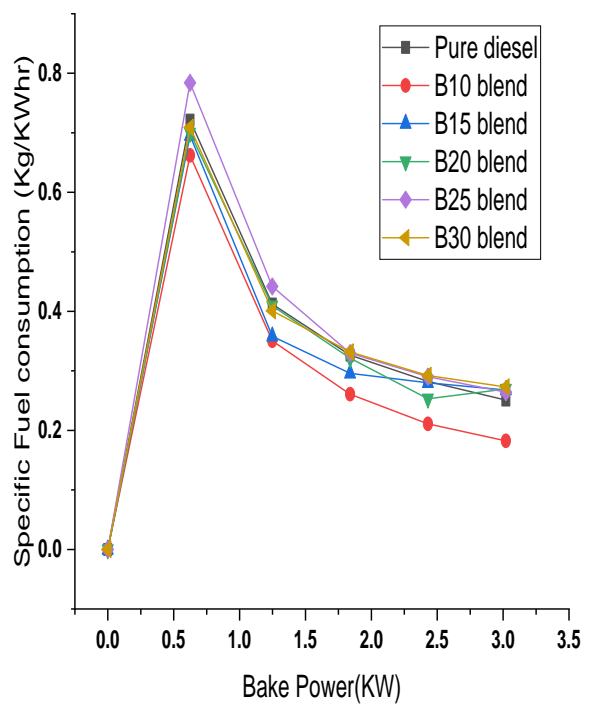

Figure 15. BP vs Specific Fuel consumption 


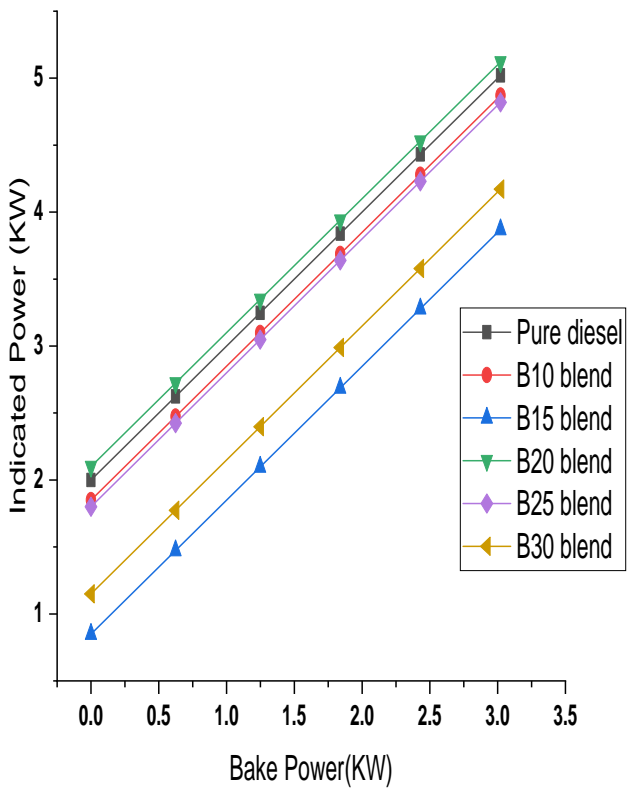

Figure 16. BP vs Mechanical efficiency

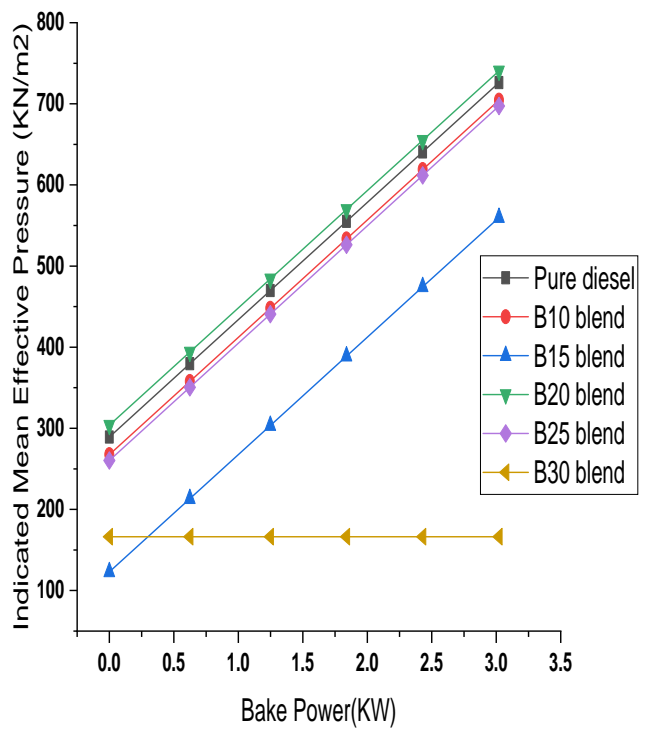

Figure 17. BP vs Indicated mean effective pressure

Fig. 6 to Fig. 17 represent the graphical representation of Brake power $(\mathrm{KW})$ with various performance parameters of an engine for different blends of bio diesel B10, B15, B20, B25 and B30. It was clearly observed from fig 6 that, blending of oil B10 exhibits lower fuel consumption of $0.55 \mathrm{Kg} / \mathrm{Kwhr}$ compared to remaining blends of oils. Blending of diesel $900 \mathrm{ml}$ with equal quantity of 50 $\mathrm{ml}$ each of pongomia and neem oil is having better fuel consumption rate than remaining blends of oils. Fig 12 and Fig 13 gives the response of brake thermal efficiency and indicated thermal efficiency for various blends of oils with respect to brake power. It was observed from fig12 and fig13 that, B10 blend possess higher brake thermal efficiency and indicated thermal efficiency with increase of brake power followed by B20 blend of oil. In terms of mechanical efficiency B15 blend possess higher mechanical efficiency with increase of brake power shown in fig 14. The specific fuel consumption for B25 blend was better compared to remaining formulations of blends of oils shown in fig 15 . The mechanical efficiency and indicated mean effective pressure are superior for B20 blend compared to remaining blends of oils shown in fig 16 and fig 17.

\section{Smoke and Exhaust gas analysis}

The major pollutants appearing in the exhaust of a diesel engine are smoke and the oxides of nitrogen. For measuring the smoke opacity, Hartridge Exhaust smoke-meter was used. Hartridge smoke meter consists of two identical tubes, a smoke type and a clean air tube. A pressure relieve valve allows a regulated quantity of exhaust through the smoke tube. During smoke density measurements, a light source (45-W bulb) at one end of the smoke tube projects a light beam through smoke, which at the other end falls on a photoelectric cell. Clean air tube is used for initial zero setting. Of the light beam projected across a flowing stream of exhaust gases, a certain portion of light is absorbed or scattered by the suspended soot particles in the exhaust. The remaining portion of the light falls on a photocell, generating a photoelectric current, which is a measure of smoke density. A microvoltmeter is connected to the photoelectric cell with its scale graduated 0-100, indicating the light absorbed in Hartridge Smoke Meter unit. Zero reading corresponds to no smoke (clean air), whereas 100 reading refers to dense smoke, which allows no light to pass through as shown in Figure 18. Hartridge exhaust smoke meter and exhaust gas analyzer used in this study is shown in fig 18 and fig 19 . 


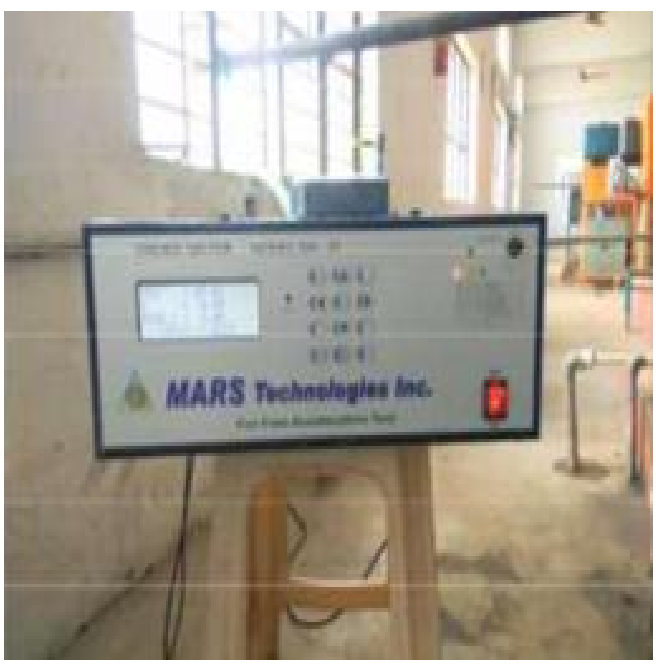

Figure 18. Hartridge Exhaust Smoke meter

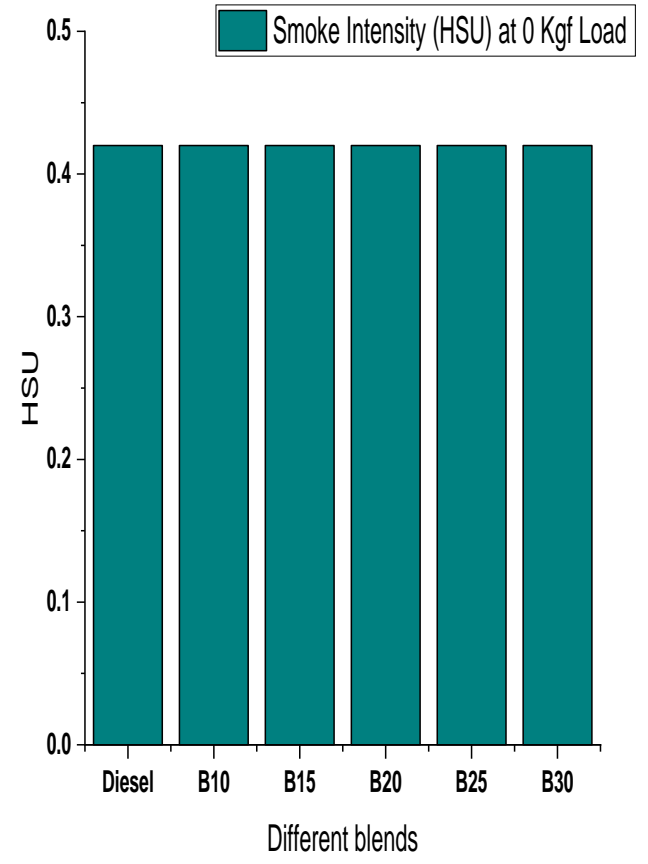

Figure 20. Smoke intensity at zero load

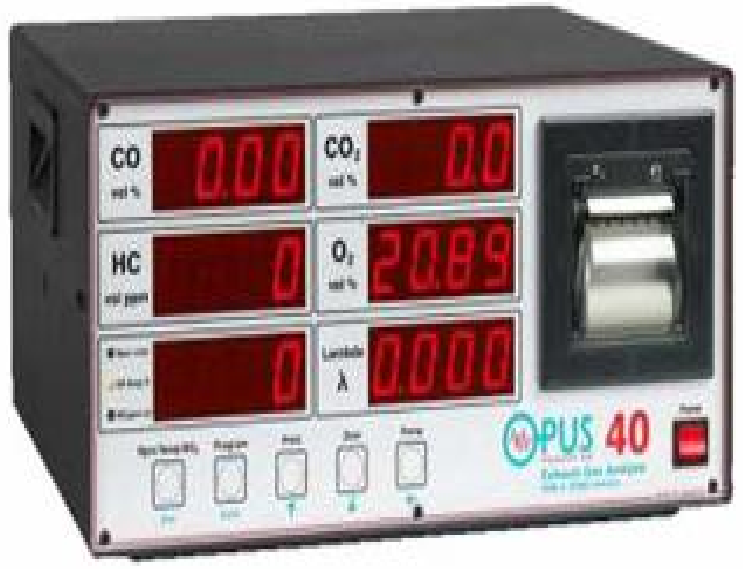

Figure 19. Exhaust gas analyzer

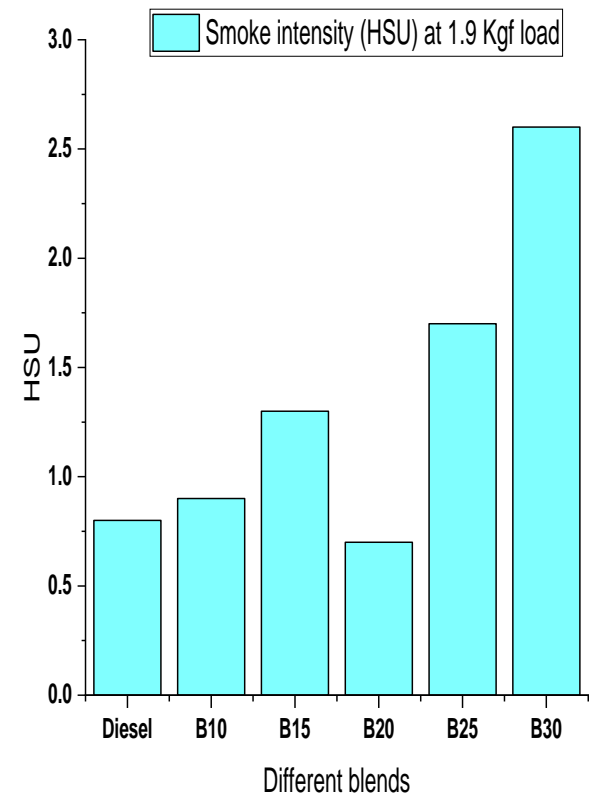

Figure 21. Smoke intensity at $1.9 \mathrm{Kgf}$ load 


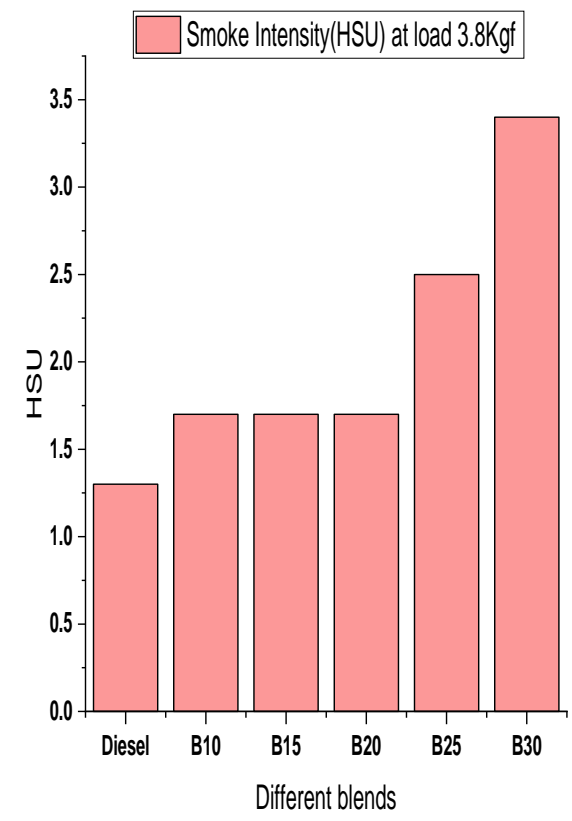

Figure 22. Smoke intensity at 3.8Kgf load

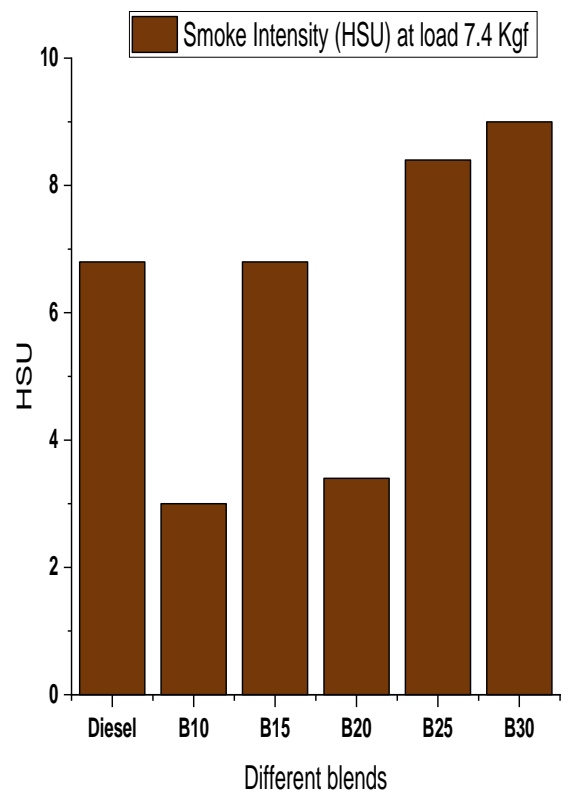

Figure 24. Smoke intensity at $7.4 \mathrm{Kgf}$ load

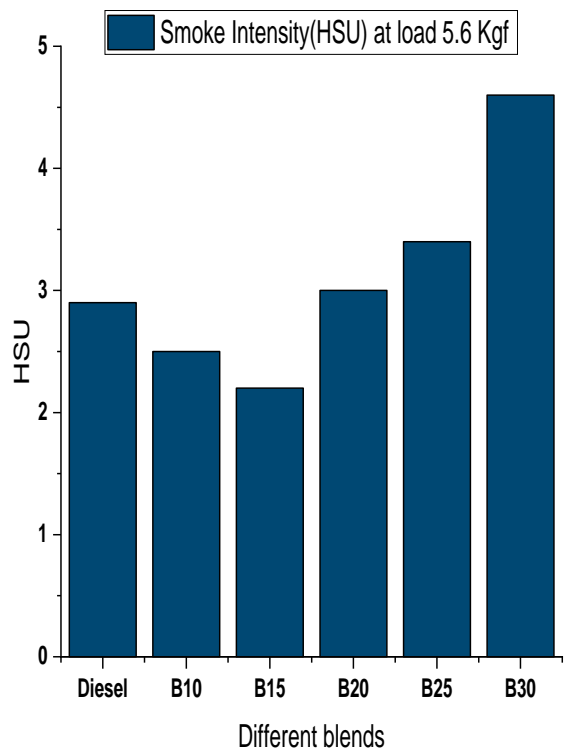

Figure 23. Smoke intensity at $5.6 \mathrm{Kgf}$ load

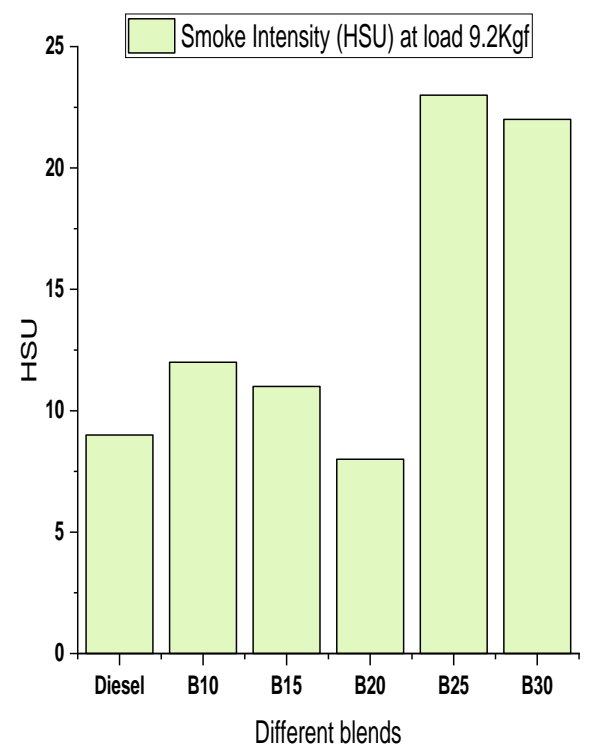

Figure 25. Smoke intensity at $9.2 \mathrm{Kgf}$ load 


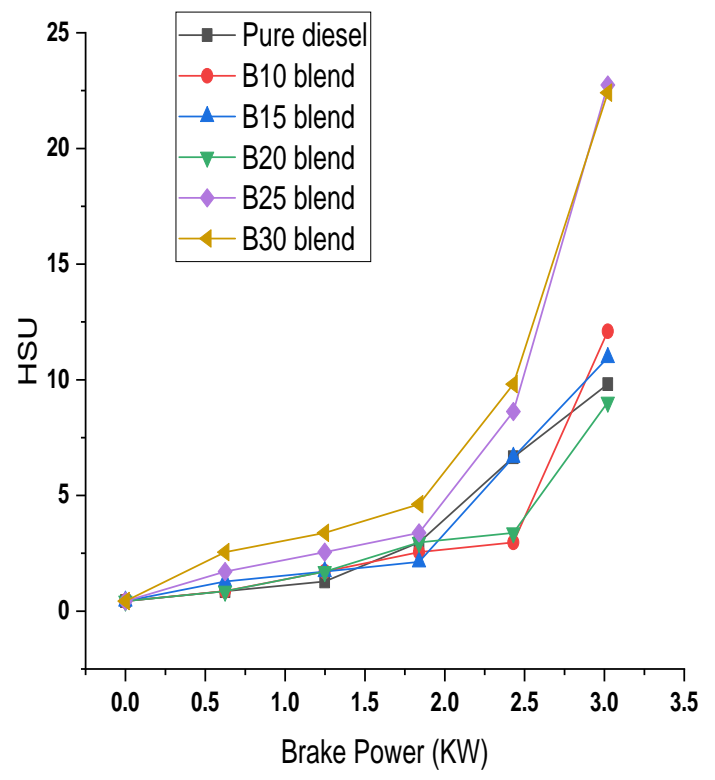

Figure 26 BP vs HSU for various blends

The amount of smoke delivered from the silencer is measured through smoke intensity meter of MARS Technologies ltd. The equipment is provided with a sensor to measure the intensity of smoke with increase of load acting on the engine. The load acting on the engine is increased from $(1.9 \mathrm{Kgf}, 3.8 \mathrm{Kgf}, 5.6 \mathrm{Kgf}, 7.4 \mathrm{Kgf}$, and $9.2 \mathrm{Kgf})$ and the response of Hartridge smoke unit (HSU) was recorded. It was observed from fig 20 to fig 26 that, B20 blend of oil exhibits better smoke intensity compared to remaining blends of oils with increase of load acting on the engine.

Exhaust gas analysis was performed by using an exhaust gas analyzer instrument for the measurement of Oxygen $\left(\mathrm{O}_{2}\right)$, Carbon Monoxide (CO), Carbon Dioxide $\left(\mathrm{CO}_{2}\right)$ and Hydrocarbons (HC's) in the exhaust gases, caused by an incorrect combustion. The presence of oxygen in the exhaust gases indicates that the combustion of the mixture was not perfect resulting in contaminant gases. Thus measuring the proportion of oxygen in the exhaust gases of these engines can monitor and measure these emissions. A rich mixture will generate a small content of oxygen in the exhaust and increased emissions of carbon monoxide and hydrocarbon. The observations made from the experimental procedure during the load test and Exhaust analysis is tabulated in the following tables (Table 9 to Table 11) and the recorded observations are represented graphically in fig 27 to fig 30.

Table 9 Observations for carbon monoxide

\begin{tabular}{|c|c|r|r|r|r|r|}
\hline Loads(kgf) & Pure diesel & \multicolumn{1}{|c|}{ B10 } & \multicolumn{1}{c|}{ B15 } & \multicolumn{1}{c|}{ B20 } & \multicolumn{1}{c|}{ B25 } & \multicolumn{1}{c|}{ B30 } \\
\hline 0 & 0.076 & 0.077 & 0.079 & 0.08 & 0.08 & 0.089 \\
\hline 1.9 & 0.077 & 0.081 & 0.083 & 0.09 & 0.092 & 0.096 \\
\hline 3.8 & 0.079 & 0.087 & 0.086 & 0.092 & 0.094 & 0.1 \\
\hline 5.6 & 0.082 & 0.09 & 0.093 & 0.099 & 0.101 & 0.102 \\
\hline 7.4 & 0.087 & 0.092 & 0.095 & 0.102 & 0.107 & 0.109 \\
\hline 9.2 & 0.092 & 0.096 & 0.098 & 0.107 & 0.113 & 0.116 \\
\hline
\end{tabular}

Table 10 Observations for carbon dioxide

\begin{tabular}{|c|c|c|c|c|c|c|}
\hline Loads(Kgf) & Pure diesel & B10 & B15 & B20 & B25 & B30 \\
\hline 0 & 2.49 & 2.26 & 2.23 & 2.21 & 2.16 & 2.83 \\
\hline 1.9 & 3.03 & 2.94 & 2.81 & 2.46 & 2.93 & 3.24 \\
\hline 3.8 & 3.63 & 3.42 & 3.07 & 2.17 & 3.11 & 4.21 \\
\hline 5.6 & 3.99 & 3.38 & 3.29 & 2.22 & 3.28 & 2.87 \\
\hline 7.4 & 4.86 & 3.81 & 3.74 & 2.87 & 4.21 & 2.23 \\
\hline 9.2 & 5.55 & 5.32 & 3.78 & 2.46 & 4.8 & 2.18 \\
\hline
\end{tabular}


Table 11 Observations for oxygen

\begin{tabular}{|c|c|c|c|c|c|c|}
\hline Loads(kgf) & Pure diesel & B10 & B15 & B20 & B25 & B30 \\
\hline 0 & 16.94 & 17.59 & 17.17 & 17.67 & 17.92 & 16.44 \\
\hline 1.9 & 16.9 & 16.6 & 16.68 & 17.32 & 16.84 & 16.39 \\
\hline 3.8 & 15.61 & 15.96 & 16.46 & 17.86 & 16.69 & 15.03 \\
\hline 5.6 & 15.07 & 15.89 & 16.03 & 17.85 & 16.42 & 16.82 \\
\hline 7.4 & 13.85 & 15.54 & 15.6 & 16.82 & 15.06 & 17.94 \\
\hline 9.2 & 12.89 & 13.13 & 15.61 & 17.96 & 14.15 & 17.75 \\
\hline
\end{tabular}

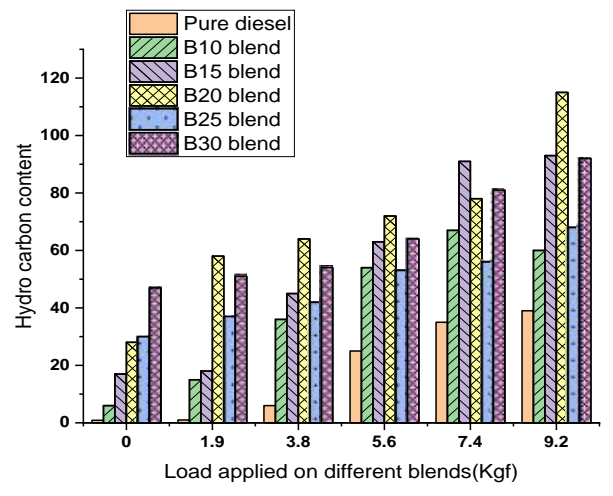

Figure 27.Load vs Hydrocarbon contents

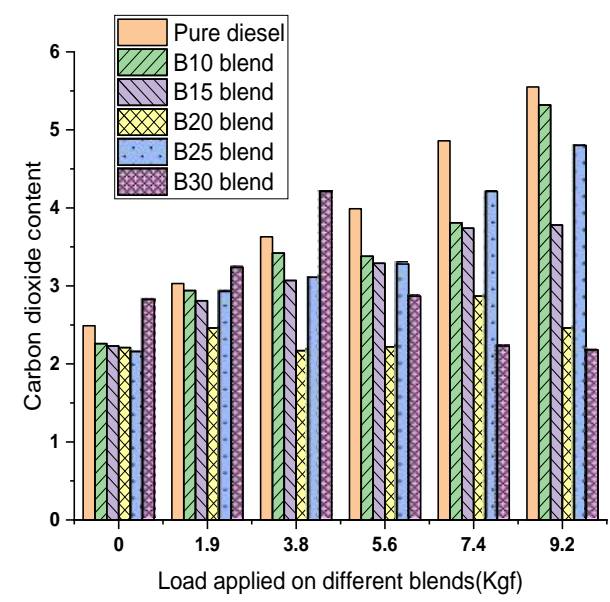

Figure 29.Load vs Carbon dioxide contents

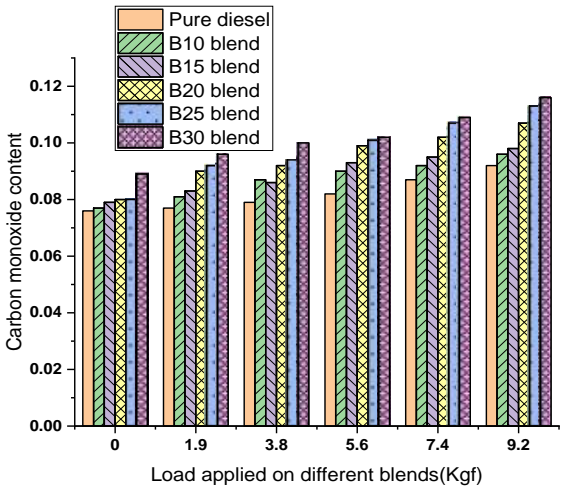

Figure 28.Load vs carbonmonoxide contents

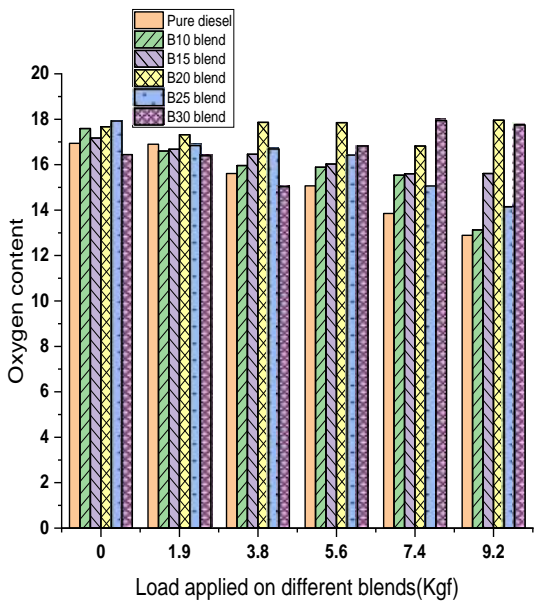

Figure 30.Load vs oxygen contents

It was observed from exhaust gas analysis results that, pure diesel is observed to possess low hydro carbon content, CO and oxygen contents with increase of load and it was also observed that, pure diesel is having more carbon dioxide content shown in Fig 29.

\section{Conclusions}

An experimental study is conducted to evaluate and compare the use of Pongomia and Neem oils as a full or partial supplement to conventional diesel fuel in IC engine. A series of tests were conducted using each of the fuels in various proportions with the engine working under the constant speed of $1500 \mathrm{rpm}$, and at different loads ranging from no load to full load. For each test performed, the performance gauging parameters such as fuel consumption, thermal efficiency, mechanical efficiency, mean effective pressures etc. were computed. The experimentation also involved measurement of smoke intensity levels and Exhaust 
Gas Analysis for each blend. Further the performance characteristics were also plotted. Based on the experimental results, the following conclusions have been drawn:

Comparing the mechanical efficiencies at different loads for all blends, it can be inferred that B15 offers the highest mechanical efficiency. Comparing the specific fuel consumption for each particular blend, it was observed that B10 has least specific fuel consumption for shaft output greater than $1 \mathrm{~kW}$. For output less than $1 \mathrm{~kW}, \mathrm{~B} 10$ seems to be the best blend. The different blends were also evaluated for the thermal efficiencies and it was observed that B10 is best mixture for brake output greater than $1 \mathrm{KW}$ and for power less than $1 \mathrm{KW}$. B20 is the best. B20 composition is the best among all blends in terms of the intensity of smoke. This conclusion is drawn based on the values of HSU obtained from the smoke analysis. It is observed that, the usage of oxygen in the air and the effectiveness of combustion is best for this blend. Pure Diesel is the best among all blends in terms of low Hydro carbons, carbon monoxide and oxygen emissions. It is having more carbon di-oxide emissions. From this point of view diesel is best for environment. Hence based on the results, B10 blend containing 90\% diesel, 5\% pongomia oil and 5\% neem oil is observed to be the best blend compared to remaining formulations. The effect of nano tubes on various blends of oils using different additives can extend this work and the influence of various bio fuels on the engine performance is taken as a challenge for the future scope.

\section{Acknowledgement}

The authors would like to thank Anits Engineering College for providing thermal engineering laboratory facilities for performing this experiment.

\section{References}

Agarwal D. and Agarwal A.K., 2007. Performance and emission characteristics of Jatropha oil (preheated and blends) in a direct injection compression ignition engine, Applied Thermal Engineering, Vol. 27, pp. 2314-2323. https://doi.org/10.1016/j.applthermaleng.2007.01.009

Dubey P., Gupta R. 2018. Influences of dual bio-fuel (Jatropha biodiesel and turpentine oil) on single cylinder variable compression ratio diesel engine. Renewable Energy, Vol. 115, pp. 1294-1302. https://doi.org/10.1016/j.renene.2017.09.055

El-Mashad H.M., Avena-Bustillos R.J. 2008. A two-step process for biodiesel production from salmon oil. Biosystems Engineering, Vol. 99, pp. 220-227. https://doi.org/10.1016/j.biosystemseng.2007.09.029

Gurbuj H., Demirturk S. 2020. Investigation of duel fuel combustion by different port injection fuels (neat ethanol and E85) in a DE95 diesel ethanol blend fueled compression ignition engine. ASME, Journal of Energy Resources Technology, Vol. 142, No. 12, pp. 122306-122315. https://doi.org/10.1115/1.4047328

Hasib Z., Hossain J., Biswas S. and Islam A., Bio-diesel from mustard oil: a renewable alternative fuel for small diesel engines, Modern Mechanical Engineering, Vol. 1 No. 2, 2011, pp. 77-83. doi:10.4236/mme.2011.12010

Kapadia H., Brahmbhatt H., Dabhi Y., Chourasia S. 2019. Investigation of emulsion and effect on emission in CI engine by using diesel and bio-diesel fuel: A review, Egyptian Journal of Petroleum, Vol. 28, pp. 323-337. https://doi.org/10.1016/j.ejpe.2019.06.004

Kapoor M., Kumar N., Verma A.S., Gautam G., Padap A.K. 2020. Performance and emission analysis of compression ignition engine with neem methyl ester mixed with cerium oxide nano particles. ASME Journal of Energy Resources Technology, Vol. 142, No. 8, pp. 082308-082317. https://doi.org/10.1115/1.4047022

Nagaraj S.K., Ponnusamy P., Muthukutti G.P. and Ponnusamy R. 2019. Emission evaluation on 3-hole and 4-hole nozzle diesel engine with Jatropha and Pongamia (Karanja) mixed bio oil. Technical note, Sustainable Environmental Research, 2019, Vol. 29, No. 13, pp. 1-7. https://doi.org/10.1186/s42834-019-0018-3

Pandian A.K., Munuswamy D.B., Radhakrishanan S., Devarajan Y., Ramakrishnan R.B.B., Nagappan B. 2018. Emission and performance analysis of a diesel engine burning cashew nut shell oil bio diesel mixed with hexanol. Petroleum Science Vol. 15, pp. 176-184. https://doi.org/10.1007/s12182-017-0208-8

Prakash T., Geo V.E., Martin L.J., Nagalingam B. 2018. Effect of ternary blends of bio-ethanol, diesel and castor oil on performance, emission and combustion in a CI engine. Renewable Energy, Vol. 122, pp. 301-309. https://doi.org/10.1016/j.renene.2018.01.070

Rajesh Y., Kolakoti A., Chandrasekhar B.G., Bhargavi J. 2019. Optimization of biodiesel production from waste frying palm oil using definitive screening deisgn. International Journal of Engineering, Science and Technology, Vol. 11, No. 2, pp. 48-57. DOI: http://dx.doi.org/10.4314/ijest.v11i2.4

Senthilkumar S., Sivakumar G., Manoharan S. 2015. Investigation of palm methyl-ester bio-diesel with additive on performance and emission characteristics of a diesel engine under 8-mode testing cycle. Alexandria Engineering Journal, Vol. 54, pp. 423428. https://doi.org/10.1016/j.aej.2015.03.019

Yadav R.K. and Sinha S.L., 2015. Performance of diesel engine using blends of conventional diesel and jatropha bio-diesel as alternative fuel for clean environment, International Journal for Research in Emerging Science and Technology, Vol. 2, No. 2, pp. 8-15. 
Yan Y.F., Zhao T., Guo H., Xu F., Zhang L., Yang Z., Ran J. 2020. Experimental investigation on mixed combustion characteristics of coal, tobacco, straw, and cylinder in an energy saving bake process. Journal of Energy Resources Technology, Vol. 143, No. 2, pp. 1-30. DOI: 10.1115/1.4047763

\section{Biographical notes}

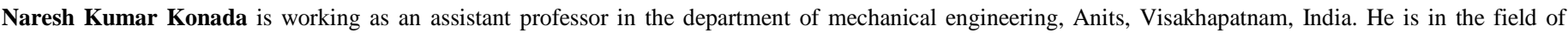
teaching and research since 2010. He published 20 international journals in various fields. He is currently pursuing PhD in the department of mechanical engineering, Andhra University. His area of interests includes machine design, nano composites, vibrations and vehicle dynamics.

K.N.S. Suman is working as an Associate professor in the department of mechanical engineering, Andhra University, Visakhapatnam, India. He received his doctorate in the year 2006 from Andhra University, in the field of research on under water vehicles in collaboration with naval science and Technological laboratory (NSTL). He received best thesis award during that year by Andhra University. He received senior research fellowships from UGC and CSIR. His area of research interests includes mechanical behaviour of composites, nano materials and manufacturing.

B.B. Ashok Kumar has completed his post graduation in the field of Industrial Engineering from Andhra University. He is presently working as an assistant professor in the department of mechanical Engineering, Anits since 2012. His areas of research interests include bio fuels, optimization and product design. 